\title{
Correction
}

\section{Correction: Ngo, T.D. LinkMind: Link Optimization in Swarming Mobile Sensor Networks. Sensors 2011, 11, 8180-8202}

\section{Trung Dung Ngo ${ }^{1,2, *}$}

1 The More-Than-One Robotics lab, Department of Electronic Systems, Automation and Control Section, Aalborg University, Fredrik Bajers Vej 7C, 9220 Aalborg, Denmark

2 Faculty of Science, University of Brunei Darussalam, Jalan Tungku Link, Gadong, BE1410, Brunei

* Author to whom correspondence should be addressed; E-Mail: dungnt@es.aau.dk;

Tel.: +45 9940 8744; Fax: +45 99408772.

Received: 25 October 2011 / Published: 26 October 2011

The author's affiliation was wrong in [1]. The "National University of Brunei" and should be "University of Brunei Darussalam".

\section{References}

1. Ngo, T.D. LinkMind: Link Optimization in Swarming Mobile Sensor Networks. Sensors 2011, 8, 8180-8202.

(C) 2011 by the authors; licensee MDPI, Basel, Switzerland. This article is an open access article distributed under the terms and conditions of the Creative Commons Attribution license (http://creativecommons.org/licenses/by/3.0/). 